\title{
Providing a foundation for road transport energy demand analysis: A vehicle parc model for South Africa
}

\author{
Adrian Stone ${ }^{1 *}$, Bruno Merven ${ }^{2}$, Tiisetso Maseela ${ }^{3}$, Resmun Moonsamy ${ }^{4}$ \\ 1. Sustainable Energy Africa, Green Building, 9B Bell Crescent Close, Westlake Business Park, Tokai 7945, \\ South Africa \\ 2. The Energy Research Centre, University of Cape Town, Rondebosch, 7700, South Africa \\ 3. Mott Macdonald, Cape Town office, Foreshore, 8001, Cape Town, South Africa \\ 4. South African National Energy Development Institute, Block C, Upper Grayston Office Park, 152 Ann \\ Crescent, Strathavon, Sandton, 2146, South Africa.
}

\begin{abstract}
It is key for national economic planning to build the tools to forecast energy demand from major sectors like transport in a credible way. As a starting point, this requires building a sufficiently detailed 'bottomup' picture of technologies and their activity levels in the recent past. A vehicle parc model was developed for South Africa to feed transport demand and data on the fleet into a national energy systems model, the South African TIMES model, which is a least-cost optimisation model of the TIMES/ MARKAL family. Detailed assumptions were developed for 24 vehicle typologies that included the vintage profile, annual mileage and its relationship with age, fuel economy and its improvement over time, and occupancy and load factor. Combining these assumptions, the model was successfully calibrated over 2000-2014 with the national registration database, national fuel sales statistics and, on the freight side, with estimates of the demand for
\end{abstract}

ton. $\mathrm{km}$ published by the University of Stellenbosch's Department of Logistics (2014 only). A demand for passenger.km was also calculated, which agreed well with national transport surveys. A range of detailed indicators were produced for the vehicle typologies and some interesting trends observed, including the steady dieselisation of the light vehicle fleet over the study period and the stagnation of passenger car fuel economy, despite legislation in the European Union. The present study believes that this updated data-rich picture of the road transport vehicle parc will support other studies and national policy and planning initiatives.

Keywords: freight demand, fuel economy, mode share, greenhouse gas emissions, vehicle fleets, modelling

Journal of Energy in Southern Africa 29(2): 29-42

DOI: http://dx.doi.org/10.17159/2413-3051/2018/v29i2a2774

Published by the Energy Research Centre, University of Cape Town ISSN: 2413-3051 http://journals.assaf.org.za/jesa

Sponsored by the Department of Science and Technology

\footnotetext{
* Corresponding author: Tel: +21 702 3622;

email: adrian@sustainable.org.za
} 


\section{Introduction}

The national energy balance for 2013 indicated that the transport sector accounted for an estimated $30 \%$ of South Africa's total final consumption (Department of Energy (DoE), 2013). The sector has remained almost completely dependent on liquid fuels, which accounted for $98 \%$ of demand in the sector in 2013 and $83 \%$ of all liquid fuels used in the economy (DoE, 2013).

Large investments and long lead times are involved in meeting the demand for liquid fuels and transporting liquid fuels from point of supply to the point of demand. In addition, the choice of primary energy and the transformation process can have substantial impacts on society and the environment. Investment decisions must, therefore, be informed by planning processes such as a national integrated energy plan. The first step in the planning process is to build an understanding of the current demand for mobility of passengers and freight in the economy and the drivers of mobility in the transport sector and develop credible scenarios of how these will evolve over time. Furthermore, the need for mobility is not something that can be directly measured or observed and, therefore, requires estimation based on a number of observable variables such as how many people are driving private vehicles, the demand for the movement of goods in the current economic environment, and how many vehicles are on the road network (Merven, et al., 2012).

The Energy Research Centre at the University of Cape Town and the South African National Energy Development Institute used the South African TIMES Model (SATIM) in 2012, which is a least-cost optimisation model of the TIMES/MARKAL family, to assess the demand for energy from transport to 2050 (Merven, et al., 2012). The outputs of that study were widely applied (Department of Environmental Affairs, 2014; DoE, 2012; DoE, 2016; Gajjar \& Mondol, 2015). A series of papers, of which this is the first, will update these outputs, improving on some of the gaps identified in the previous work and presenting new work based on outputs of a version of the SATIM energy systems model that is linked to an economic model (Merven et al., 2017). This first paper will focus on the multiyear calibration of the model using historical data and present a detailed picture of the national freight and passenger road transport system. The main improvement on the previous work is a longer historical window for calibration and more granular detail on heavy commercial vehicles so that the demand for freight (ton.km) could be calibrated to the national figure published by the Department of Logistics, University of Stellenbosch (Havenga, et al., 2016a). The data-rich picture presented is intended to support the development of projections of transport energy sector demand for infrastructure planning purposes, the compilation of greenhouse gas inventories, and the assessment of greenhouse gas mitigation measures, amongst other uses.

\section{The demographics of the vehicle parc in South Africa}

South Africa is made up of nine provinces of marked difference in size, population density and levels of economic activity, as shown in Table 1. Economic activity and car ownership are highly concentrated in small but densely populated Gauteng, for example, in contrast to the arid and sparsely populated Northern Cape. Three provinces - Western Cape, Gauteng, and Kwazulu-Natal with the country's biggest port, Durban - together account for $55 \%$ of the population, $69 \%$ of registered vehicles and $64 \%$ of gross domestic product. Much of this activity is concentrated in the cities of Cape Town, Johannesburg, Pretoria and Durban. This geography drives a large demand for transport, allowing the country to be described as having a 'spatially challenged economy' (CSIR, 2013).

The average total motorisation for South Africa, estimated for mid-2016 at 192 vehicles per thou-

Table 1: Demographics and motorisation of South Africa's provinces.

\begin{tabular}{lcccccc}
\hline Province & $\begin{array}{c}\text { Population } \\
\text { (mid 2016) }\end{array}$ & $\begin{array}{c}\text { Total self-propelled } \\
\text { vehicles } \\
\text { (mid 2016) }\end{array}$ & $\begin{array}{c}\text { Share of } \\
\text { vehicles (\%) }\end{array}$ & $\begin{array}{c}\text { Motorisation } \\
\text { (vehicle/1000 } \\
\text { persons) }\end{array}$ & $\begin{array}{c}\text { Contribution to } \\
\text { national GDP } \\
(2015)^{3} \text { (\%) }\end{array}$ & $\begin{array}{c}\text { Land area } \\
\text { share (\%) }\end{array}$ \\
\hline Eastern Cape & 7061700 & 719939 & 6.7 & 102 & 7.8 & 14.0 \\
Free State & 2861600 & 527459 & 4.9 & 184 & 5.1 & 11.0 \\
Gauteng & 13498200 & 4163142 & 39.0 & 308 & 34.0 & 1.5 \\
KwaZulu-Natal & 11079700 & 1477700 & 14.0 & 133 & 16.0 & 7.7 \\
Limpopo & 5803900 & 604318 & 5.6 & 104 & 7.2 & 10.0 \\
Mpumalanga & 4328300 & 733541 & 6.8 & 169 & 7.5 & 6.0 \\
Northern Cape & 1191700 & 234453 & 2.2 & 197 & 2.1 & 31.0 \\
North West & 3790600 & 528044 & 4.9 & 139 & 6.5 & 8.7 \\
Western Cape & 6293200 & 1721222 & 16.0 & 274 & 14.0 & 11.0 \\
Total & 55908900 & 10709818 & 100.0 & 192 & 100.0 & 100.0 \\
\hline 1 $=$ StatsSA (2016a) ${ }^{2}=\mathrm{eNaTiS} \mathrm{(2016),}{ }^{3}=$ StatsSA (2016) & & &
\end{tabular}


sand inhabitants, now just exceeds the global average of 180 and is considerably more than the African average of about 44 (Organisation Internationale des Constructeurs d'Automobiles, 2016). But, even for the outlier of Gauteng, vehicle ownership is significantly lower than the 500 to 800 for developed countries and is more comparable to the BRICS counterparts of Russia and Brazil.

\section{Modelling transport demand}

In a bottom-up approach, energy consumption by any transport sector is directly driven by two factors: vehicle-km travelled, and conversion efficiency of the vehicle (referring to a road, rail or air vehicle). The vehicle-km travelled are in turn driven by the needs of society and the economy to move people and goods. Conversion efficiency depends mostly on the underlying technology, i.e., type of vehicle, fuel and vintage that make up the vehicle parc, and to some degree the patterns of utilisation of that technology. It is useful to treat passenger transport and freight transport separately, as the needs for moving people and goods have slightly different drivers and technologies.

(Armenia et al. 2010) proposed a detailed systems dynamics model, depicted by the causal loop in Figure 1, to represent the demand for mobility and energy consumption of passenger transport. The model includes a number of drivers and interactions which define energy consumption in pas- senger transport and illustrates the complex interactions and extensive data needs required to effectively model this sector. A diagram for road freight transport would be similar, in that fuel consumption is still the direct result of vehicle-km travelled and vehicle fuel efficiency. Several of the elements in Figure 1 are included in the calibrated vehicle parc model in the present study. These are: distance travelled per vehicle, total kilometres travelled, fuel consumption, fuel efficiency, total vehicle fleet, and average age of vehicles. Certain factors in Figure 1 affecting the vehicle-km travelled and fuel efficien$c y$, such as traffic congestion, are difficult to quantify as they are not well understood locally. To compensate for this, the model was calibrated by adjusting the variables until the output matches the known fuel sales data. Once calibrated, the present study could be reasonably sure that the model returns realistic estimates of the number of operating vehicles and their annual distance travelled. By making an informed assumption regarding the average occupancies of different vehicle types, total private travel demand could be estimated.

\section{Research methodology}

SATIM is an energy-economic-environment systems modelling framework developed by the Energy Research Centre, University of Cape Town (Altieri, 2015; Energy Research Centre, 2015). It is developed according to ETSAP's TIMES modelling

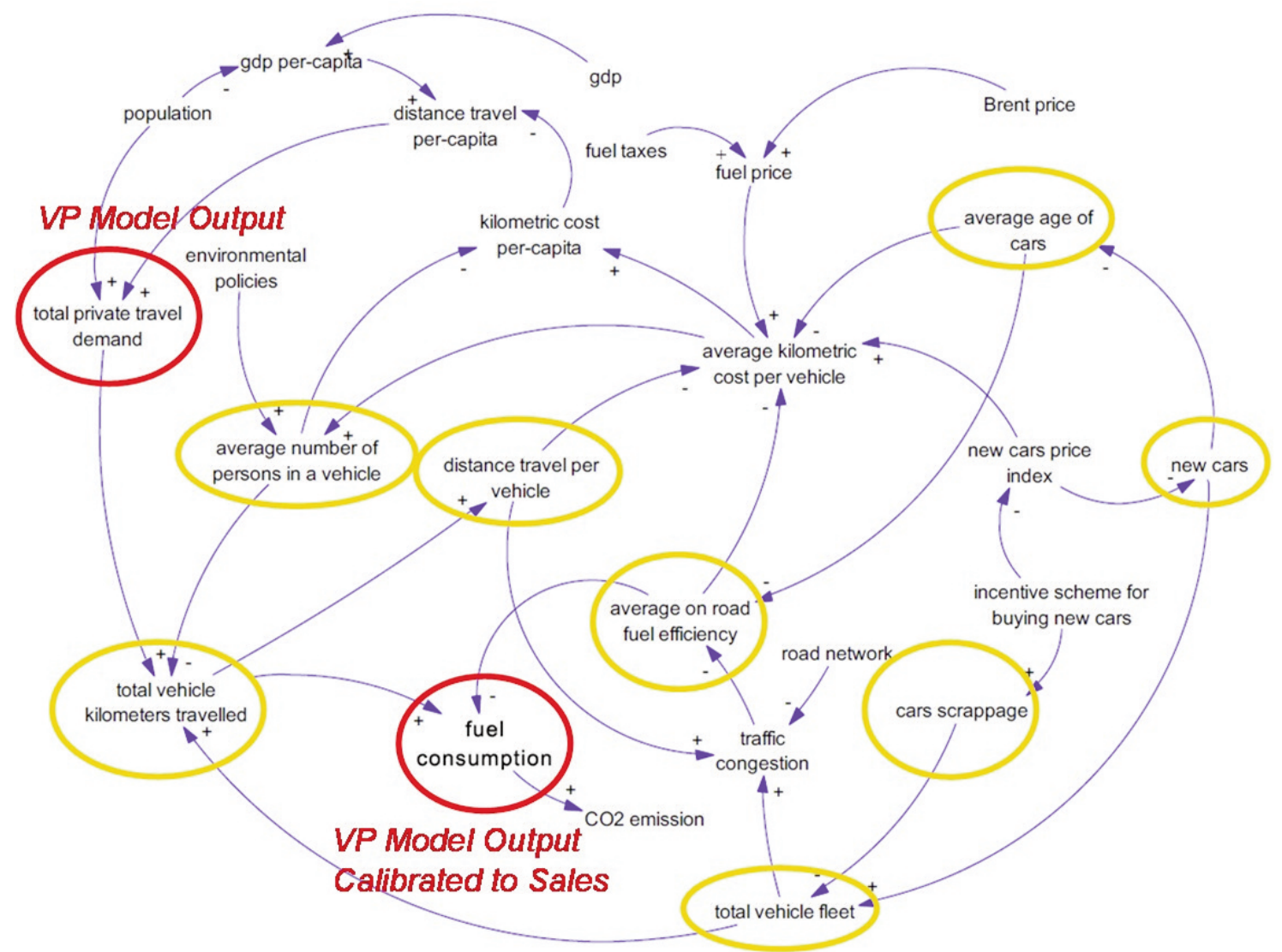

Figure 1: Causal diagram for energy needs for passenger transportation (Armenia et al., 2010). 
framework, which has been linked to a computational general equilibrium model known as eSAGE. Both tools are developed using the general algebraic modelling system, but a number of supporting models developed on other platforms also support the modelling framework, as shown in Figure 2.

The present study focused on methodology, assumptions and outputs of the vehicle parc model component of the modelling framework hown in the highlighted textbox in Figure 2. The function of this model is to build a 'bottom-up' picture of the vehicle parc that can be used to generate a credible estimate of the following key variables to enable the energy system model (TIMES) to project energy demand forward:

- $\quad$ public and private passenger.km by mode/vehicle typology (e.g., gasoline minibus public or diesel car private);

- freight ton.km by mode/vehicle typology (e.g. gasoline light commercial vehicle (LCV)); and

- the stock, vintaged by age, of each typology and representative activity (annual mileage) and efficiency assumptions for each typology. These assumptions need to be calibrated so that the fuel demand of the model matches supply side data (fuel sales) as closely as possible.

The road vehicle parc is characterised by a long vintage window of around 30 years, given the high average age of stock in South Africa. The characteristics of new stock added and the activity levels of old stock can change annually. Thus, while calculations in this type of model are possible, the multiplication of many large arrays is required. Lumina's Analytica platform (http:/www.lumina.com/), an array-based modelling tool with a powerful visual interface, was selected for the first study (Merven et al., 2012) for this reason. This vehicle parc model was updated for the present study and extended as follows:

- heavy commercial vehicles which were a single aggregate in the first study were disaggregated into nine vehicle typologies to assist with calibrating the model to the estimate of freight demand (ton.km) published by the Department of Logistics, University of Stellenbosch (Havenga, et al., 2016a);

- extension of the calibration window from seven to 14 years, spanning 2000-2013; and

- a parallel version in the open source $\mathrm{R}$ language was coded to aid collaboration; final calibration was performed in the $\mathrm{R}$ version.

\subsection{Calculation and calibration}

A schematic representation of the vehicle parc model and its data inputs and validations is shown in Figure 3. The procedure for calculation and calibration using the above parameters was broadly as follows:

1. Historic vehicle sales data collected by the National Association of Automobile Manufacturers of South Africa (Lightstone Auto, 2015) were adjusted by scrapping curves to develop an estimate of the stock of vehicles of different vehicle types for each model year, and the estimate was calibrated to the electronic national administration traffic information system (eNaTiS) registration database (eNaTiS, 2016) by adjusting the rate of scrapping.

2. Vehicle mileage estimates were developed for both passenger and freight vehicles, assuming that the annual mileage travelled by vehicles decays from an initial value as they age.

3. Fuel demand was calculated by multiplying the

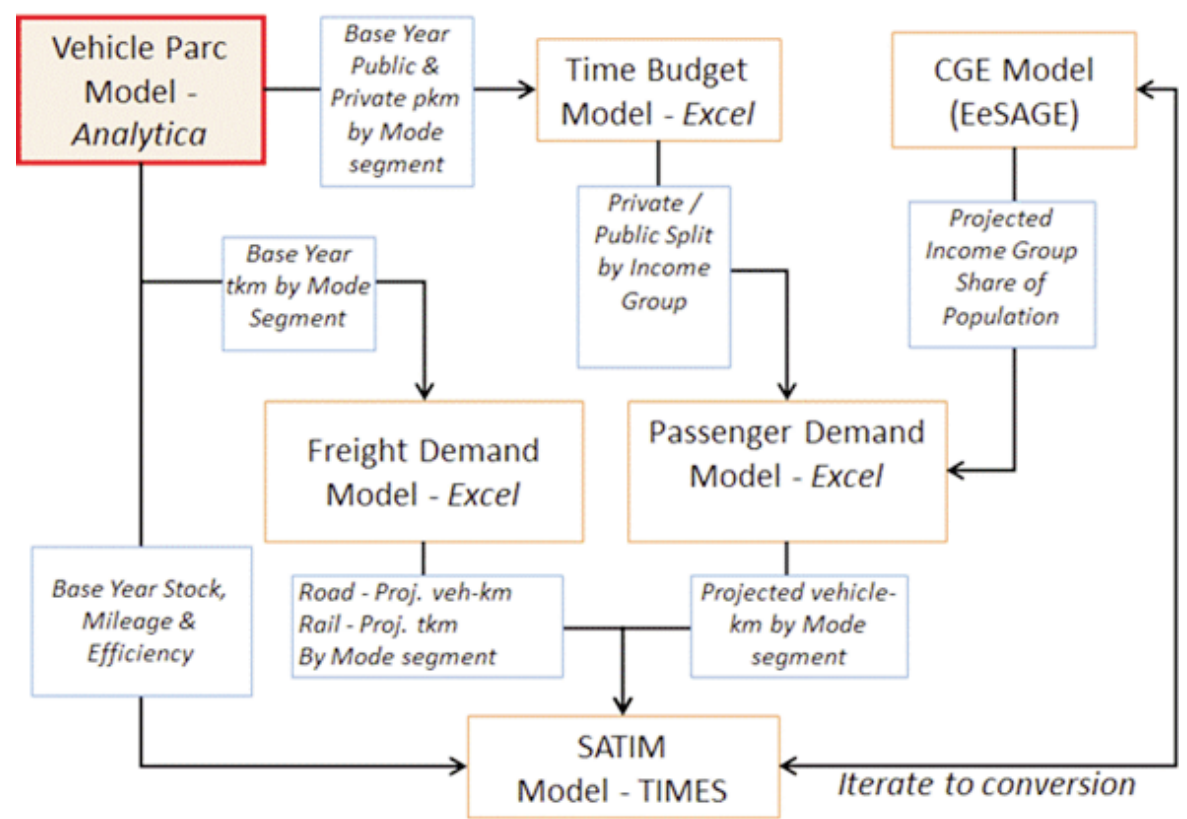

Figure 2: The SATIM transport modelling framework. 


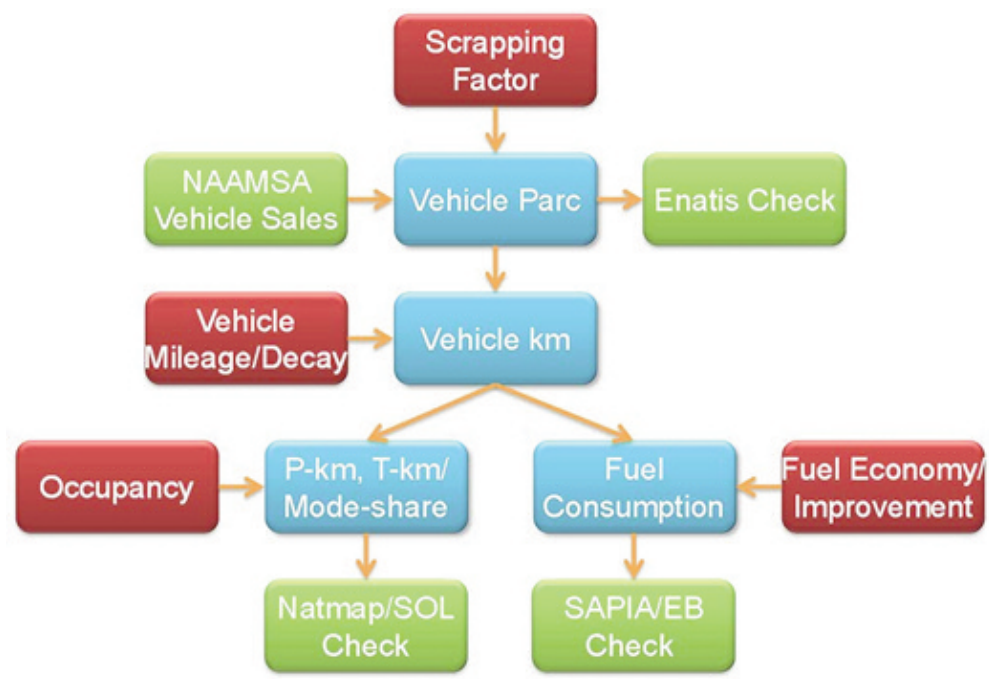

Figure 3: Schematic representation of the vehicle parc model and its data inputs and validations.

kilometres travelled, the fuel economy, and the number of vehicles for a vehicle typology. The typology fuel demands were summed to yield the vehicle parc fuel demand for gasoline and diesel and compared with aggregate fuel sales data.

4. An additional step for freight vehicles involved adjusting the average maximum capacity, capacity factor and mileage so that the model calibrated not only against fuel sales but also against published estimates of ton.km road freight demand found in the literature (Havenga, et al., 2016a).

\subsection{Vehicle typologies and calibration targets}

The typologies adopted for the vehicle parc model are presented in Tables 2 and 3, mapped to fuel type and more aggregate classifications. The aim for the model was to calibrate model fuel demand against data on road transport fuel sales across a window of 2000-2014. In the case of gasoline, $100 \%$ of sales were assumed to be used by road transport, but this was challenging in the case of diesel because, unlike gasoline, diesel is used for a wide range of off-road and stationary uses, including the fuelling of Eskom's Ankerlig and Gourikwa power stations since 2007. The South African Petroleum Industry Association (SAPIA) and its members disaggregate fuel sales using a quasi-sector typology called trade categories, and this data is then collated and made available on request by the DoE (DoE, 2017). These categories offer some indication of what portion of diesel is used by road transport if an assumption of the share of road transport diesel can be made for each trade category. An assumed share of road transport in each trade category was adjusted iteratively until there was a relatively smooth trend in the shares of the sector demands over time, as shown in Figure 4. The resulting road transport share of diesel was used to estimate a diesel calibration target for the model.

\subsection{Other calibration aspects}

4.3.1 Vintage profile

It is necessary to estimate the distribution of vehicles of different ages and technology levels in the parc, known as the vintage profile, to assess the impacts of new technologies entering the market such as on energy demand. The vintage profile can be determined by establishing a distribution of the probability of a vehicle surviving as a function of its age for each vehicle typology. Further detail on how this was done is provided in the supplementary file. ${ }^{1}$

\subsubsection{Vehicle mileage}

The annual mileage of vehicles, when averaged over a large number, appeared to decay steadily from an initial value for each year of operation (Jackson, 2001; University of California at Riverside, 2002). This is important because it means that older, more-polluting vehicles would contribute proportionally less to transport demand than newer vehicles. This data is, however, not mandatory for capturing in the South African licence-renewal process and was not available. Mileage assumptions based on the United States Environmental Protection Agency's Mobile6 model methodology (Jackson, 2001) were, therefore, adopted and scaled into the calibration process. Further detail on how this was done is provided in the supplementary file.

\subsubsection{Fuel economy}

The fuel economy of new vehicles was considered to decrease by $0.5 \%$ per annum between 2000 and 2014 for model implementation in the present study. This value was generally consistent with the more specific values in Europe during the period used in the present study. Details can be seen in the supplementary file. 
Table 2: Typology of vehicle parc model mapped to aggregate categories: passenger vehicles.

\begin{tabular}{|c|c|c|}
\hline $\begin{array}{l}\text { Vehicle type (eNatis } \\
\text { and the SATIM } \\
\text { energy system model) }\end{array}$ & Fuel type & $\begin{array}{c}\text { Vehicle parc } \\
\text { model ID* }\end{array}$ \\
\hline Passenger car & Diesel & CarDiesel \\
\hline Passenger car & Gasoline & Gasoline \\
\hline Passenger car & Diesel & CarHybridDiesel \\
\hline Passenger car & Gasoline & CarHybridGasoline \\
\hline Passenger car & Electricity & CarElectric \\
\hline Bus & Diesel & BusDiesel \\
\hline Minibus taxi & Diesel & MBTDiesel \\
\hline Minibus taxi & Gasoline & MBTGasoline \\
\hline Sport utility vehicle & Diese & ISUVDiesel \\
\hline Sport utility vehicle & Gasoline & SUVGasoline \\
\hline Sport utility vehicle & Gasoline & SUVHybridGasoline \\
\hline Motorcycle & Gasoline & MotoGasoline \\
\hline
\end{tabular}

\subsubsection{Occupancy and load factor}

No published local empirical data was available to guide the deliberations for vehicle occupancy and load factor needed to calculate the demand for the model's passenger.km and ton. $\mathrm{km}$. Initial freight load factors were drawn from the Road Freight Association's (RFA's) vehicle cost schedule (RFA, 2009) and then calibrated to the ton.km estimate for 2014 published by the Department of Logistics,
Table 3: Typology of vehicle parc model mapped aggregate: Freight vehicles.

\begin{tabular}{|c|c|c|c|}
\hline $\begin{array}{l}\text { Vehicle } \\
\text { type }\end{array}$ & $\begin{array}{c}\text { Weight } \\
\text { typology (kg) }\end{array}$ & Fuel type & Model ID* \\
\hline$\overline{\mathrm{LCV}}$ & $<3000$ & Diesel & LCVDiesel \\
\hline LCV & $<3000$ & Gasoline & LCVGasoline \\
\hline $\mathrm{MCV}$ & $3000-7500$ & Gasoline & HCV1Gasoline \\
\hline $\mathrm{MCV}$ & $3000-7500$ & Diesel & HCV1Diesel \\
\hline $\mathrm{HCV}$ & 7 501-12 000 & Diesel & HCV2Diesel \\
\hline $\mathrm{HCV}$ & $12001-16000$ & Diesel & HCV3Diesel \\
\hline $\mathrm{HCV}$ & $16001-20000$ & Diesel & HCV4Diesel \\
\hline $\mathrm{HCV}$ & $20001-24000$ & Diesel & HCV5Diesel \\
\hline $\mathrm{HCV}$ & $24001-32000$ & Diesel & HCV6Diesel \\
\hline $\mathrm{EHCV}$ & $32001-40000$ & Diesel & HCV7Diesel \\
\hline $\mathrm{EHCV}$ & $40001-50000$ & Diesel & HCV8Diesel \\
\hline $\mathrm{EHCV}$ & $>50000$ & Diesel & HCV9Diesel \\
\hline \multicolumn{4}{|c|}{$\begin{array}{l}\mathrm{LCV}=\text { light commercial vehicle; } \mathrm{MCV}=\text { medium commercial } \\
\text { vehicle; } \mathrm{HCV}=\text { heavy commercial vehicle; } \mathrm{EHCV}=\text { extra- } \\
\text { heavy commercial vehicle } \\
\text { * These IDs are used in graph and tables in the following } \\
\text { sections }\end{array}$} \\
\hline
\end{tabular}

University of Stellenbosch (Havenga, et al., 2016a). The occupancy for passenger vehicle was taken from Merven et al. (2012). Details on load factors and occupancy can be seen in the supplementary file. $^{1}$

\section{Results and discussion}

The model achieved a generally good calibration for vehicle population and fuel demand and generated a number of statistics of interest for the South African vehicle parc. The aggregate calibration of the model with the registration database eNaTiS showed agreement within 3\%, as shown in Figure 5.

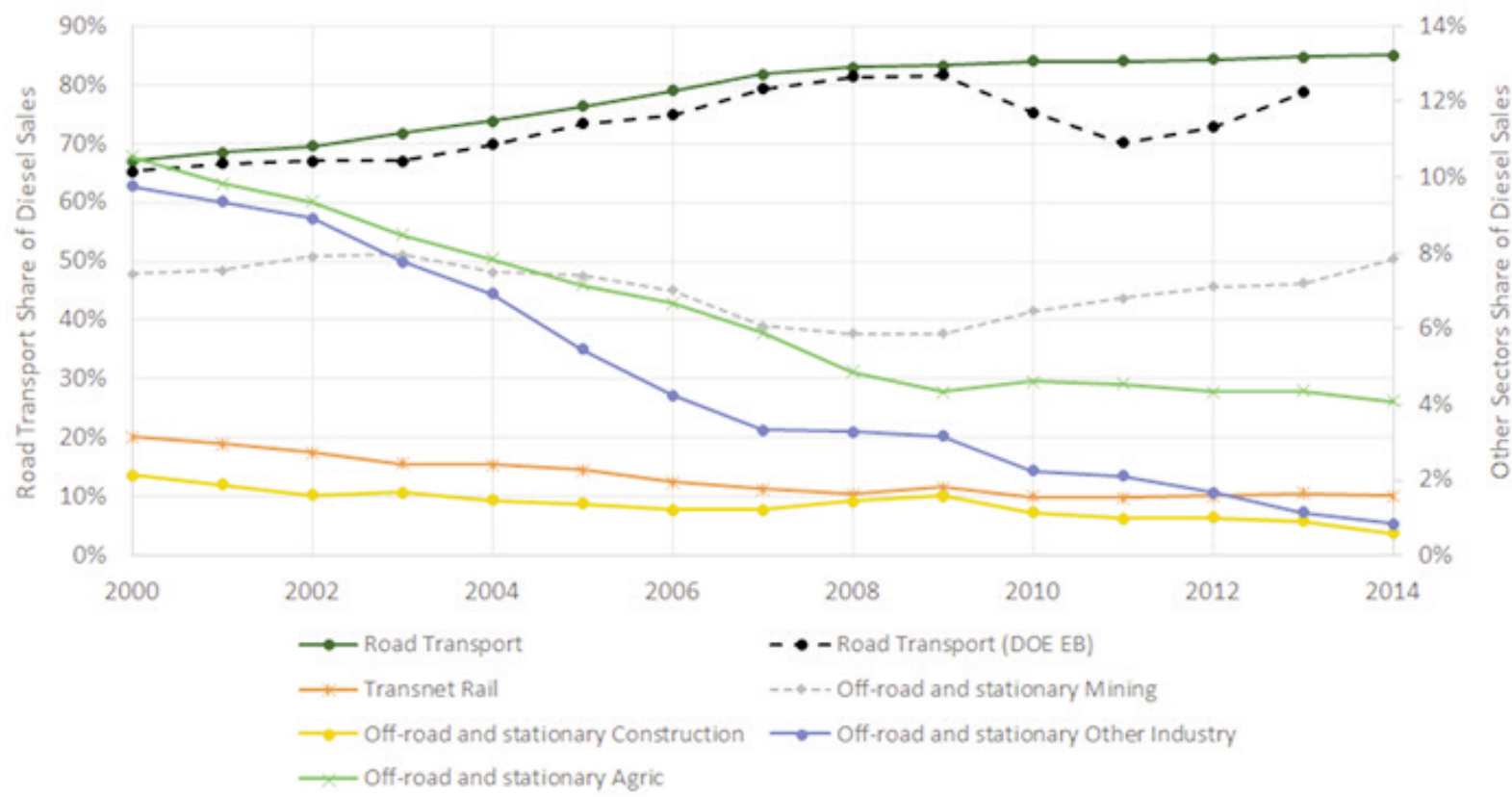

Figure 4: Estimate of road transport share of diesel sales less Eskom consumption for calibration, where DOE EB: DoE's energy balances. 


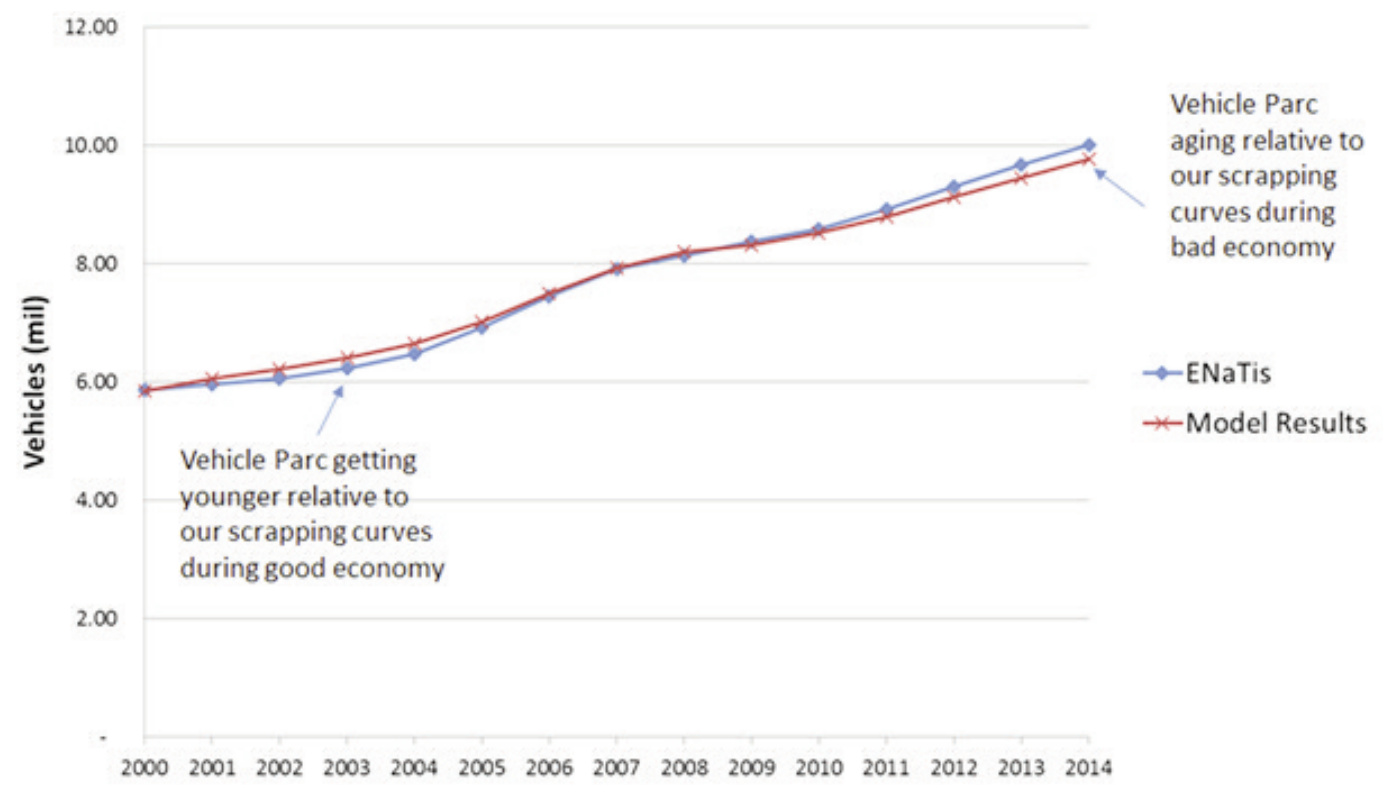

Figure 5: Calibrated vehicle parc model compared to the eNATiS registration database.

This allowed the split of the vehicle parc into its typologies with some level of confidence, as presented in Tables 4 and 5 .

The model indicated steady dieselisation of the light vehicle fleet between 2000 and 2014, as shown in Figure 6. The registration database (eNaTiS, 2016) has included a split between diesel and gasoline vehicles since 2015, and the model output compared well with this data.

The demand for passenger.km was calculated by multiplying the calculated vehicle. $\mathrm{km}$ with the assumed occupancy presented in Table 6 for each typology. The results show good agreement with other studies (NATMAP, 2005; NHTS, 2013). South Africa's car-driving, high-income households and low-income public transport users live in peripheral

Table 4: Vehicle typologies as a fraction of the passenger road vehicle parc for 2010.

\begin{tabular}{lcc}
\hline $\begin{array}{l}\text { Vehicle typology } \\
\text { CarDiesel }\end{array}$ & $\begin{array}{c}\text { Count of vehicles } \\
\text { (2010) }\end{array}$ & $\begin{array}{c}\text { Fraction } \\
\text { (\%) }\end{array}$ \\
\hline CarGasoline & 221779 & 3.6 \\
\hline CarHybridDiesel & 4832681 & 78.3 \\
\hline CarHybridGasoline & 1113 & 0.0 \\
\hline CarElectic & 0 & 0.0 \\
\hline BusDiesel & 21686 & 0.0 \\
\hline${ }^{*}$ MBTDiesel & 23911 & 0.4 \\
\hline${ }^{*}$ MBTGasoline & 277064 & 0.4 \\
\hline SUVDiesel & 171630 & 4.5 \\
\hline SUVGasoline & 252050 & 2.8 \\
\hline SUVHybridGasoline & 541 & 4.1 \\
\hline MotoGasoline & 372534 & 0.0 \\
\hline Total & $6174988^{*}$ & 100.0 \\
\hline * Total not calibrated to include the 'Other self-propelled \\
vehicles' category in the eNaTiS registration database.
\end{tabular}

sprawl, so average trip distance is likely to be similar across modes, so motorised trip-based mode share and passenger. $\mathrm{km}$ mode share compare reasonably well.

Similarly, the demand for freight transport in ton.km was calculated by multiplying the calculated vehicle. $\mathrm{km}$ with the assumed load factors, as presented in Table 8, for each typology. In this case, however, the load factors were derived from a calibration process against a published figure of 231 billion ton.km for 2014 (Havenga, et al., 2016a). The detailed calibration results, including a split by vehicle typology and corridor, metropolitan and rural operating environments are presented in Appendix A in the supplementary file.

The energy intensity of road freight transport

Table 5: Vehicle typologies as a fraction of the freight road vehicle parc for 2010.

\begin{tabular}{lcc}
\hline Vehicle typology & $\begin{array}{c}\text { Count of vehicles } \\
\text { (2010) }\end{array}$ & $\begin{array}{c}\text { Fraction } \\
\text { (\%) }\end{array}$ \\
\hline LCVDiesel & 852698 & 33.2 \\
\hline LCVGasoline & 1394106 & 54.2 \\
\hline HCV1Gasoline & 6061 & 0.2 \\
\hline HCV1Diesel & 120270 & 4.7 \\
\hline HCV2Diesel & 31074 & 1.2 \\
\hline HCV3Diesel & 53763 & 2.1 \\
\hline HCV4Diesel & 12249 & 0.5 \\
\hline HCV5Diesel & 5146 & 0.2 \\
\hline HCV6Diesel & 74175 & 2.9 \\
\hline HCV7Diesel & 19406 & 0.8 \\
\hline HCV8Diesel & 434 & 0,0 \\
\hline HCV9Diesel & 514 & 0.0 \\
\hline Total & $2569897 * 0.0$ \\
\hline Total not calibrated to include the 'Other self-propelled \\
vehicles' category in the eNaTiS registration database.
\end{tabular}




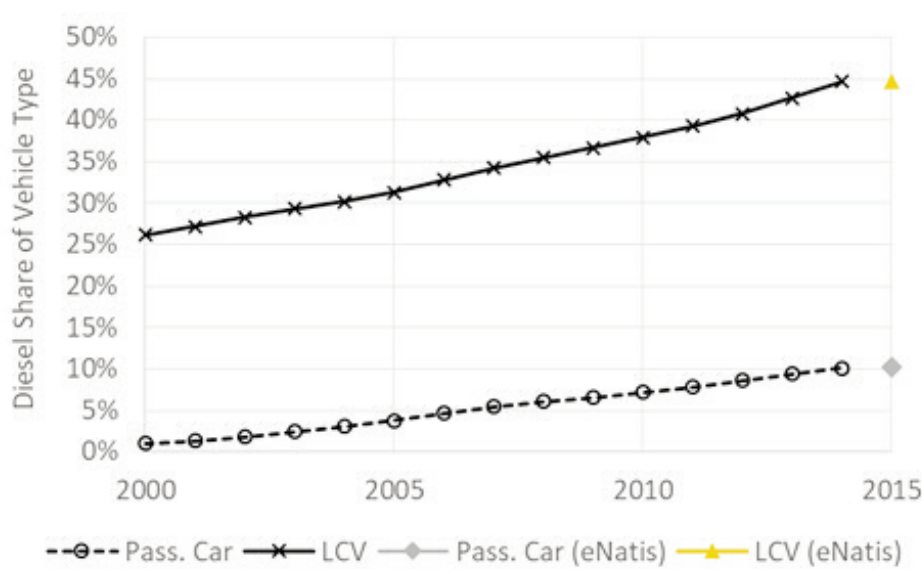

Figure 6: Modelling trend in dieselisation of the light vehicle fleet compared with the registration database for 2015.

Table 6: Model-generated passenger transport data for South Africa (2014).

\begin{tabular}{|c|c|c|c|c|c|c|c|c|}
\hline & $\begin{array}{c}\text { Total } \\
\text { vehicles } \\
\text { (1000 } \\
\text { vehicles) }\end{array}$ & $\begin{array}{c}\text { Total } \\
\text { vehicle-km } \\
\text { (billion } \\
\text { vehicle- } k m \text { ) }\end{array}$ & $\begin{array}{c}\text { Km per } \\
\text { vehicle } \\
(1000 \\
\mathrm{km})\end{array}$ & $\begin{array}{l}\text { Occupancy } \\
\text { (person/ } \\
\text { vehicle, \%) }\end{array}$ & $\begin{array}{l}\text { Activity } \\
\text { (billion } \\
\text { p.km) }\end{array}$ & $\begin{array}{l}\text { Modal share } \\
\text { (2014) } \\
(\%) \text { of p.km }\end{array}$ & $\begin{array}{l}\text { NATMAPa } \\
\text { (2005) (\%) } \\
\text { of motor- } \\
\text { ised trips }\end{array}$ & $\begin{array}{l}\text { NHTS }^{b} \\
\text { (2013)(\%) } \\
\text { of motor- } \\
\text { ised trips }\end{array}$ \\
\hline \multicolumn{9}{|c|}{ Public } \\
\hline Large bus & 23 & 0.61 & 26.1 & 25 & 15.2 & 6 & 10 & 8 \\
\hline MBT & 278 & 7.40 & 26.6 & 14 & 103.7 & 38 & 40 & 35 \\
\hline Train $^{c}$ & & & & & 13.9 & 5 & 8 & 5 \\
\hline Sub-total & & & & & 132.7 & 49 & 58 & 48 \\
\hline \multicolumn{9}{|c|}{ Private } \\
\hline Pass. car & 5722 & 83.5 & 14.6 & 1.4 & 116.9 & 43.0 & & 52.0 \\
\hline SUV & 644 & 12.8 & 19.9 & 1.4 & 18.0 & 7.0 & & \\
\hline $\mathrm{M} /$ cycle & 478 & 3.6 & 7.6 & 1.1 & 4.0 & 1.5 & & 0.4 \\
\hline Sub-total & & & & & 138.9 & 51.5 & 40.0 & 52.4 \\
\hline Grand total & & & & & 271.6 & & & \\
\hline
\end{tabular}

(a) Source: DoT, 2009

(b) Source: Stats SA, 2013 - Calculated by mode taken on allocated travel day - NOT stated mode preference.

(c) Train data from literature, not the model - Intra $\square$ city data only for 2006/2007 (Metrorail, 2007). Data for inter-city is not published by the respective vendors

$\mathrm{P} . \mathrm{km}=$ passenger, NATMAP $=$ National transport masterplan, NHTS $=$ National household travel survey, MBT $=$ Minibus taxi.

was estimated to be $1.9-2.0 \mathrm{MJ} /$ ton.km by dividing the estimated diesel sales to road transport (the calibration target) and the model's forecast of road freight diesel demand by the demand in ton.km. The result compares favourably with international data for similar markets, such as Australia (shown as AUS in Figure 7).

Figure 8 shows that the model had excellent agreement with both gasoline and diesel use during the calibration years 2000 to 2014, with the exception of gasoline in 2014 , thus providing validation for the model and the indicators generated from it.

In the version of the model developed for the present study, the calibration period was extended compared to the period used in Merven et al. (2012), resulting in a relatively less-close fit to real world data, but still within acceptable bounds for this type of model. The standard deviation of errors was $4.8 \%$ for both gasoline and diesel and was well under 10\%, except for the outliers in 2014 (11\%). The parameters input to the model in this study as compared with Merven et al. (2012) can be contrasted using Phase 1 column in Table 7, and in the tables in the supplementary section. A comparison for gasoline cars only is presented in Table 7.

Both fuel economy and mileage in the present study are about $10 \%$ lower, which may reflect an improved estimate because of the longer calibration window, but to some extent the differences also arise from the pressure on the calibration of outliers in demand in 2008, 2013 and 2014. The possible causes for this are discussed in more detail below. The data presented in Table 13 of the supplementary file implies that the fuel consumption improvement was relatively low at $0.5 \%$ per annum over the study period. The population of gasoline vehicles, however, still grows at over $3 \%$ per annum, despite dieselisation. If vehicle mileage was con- 


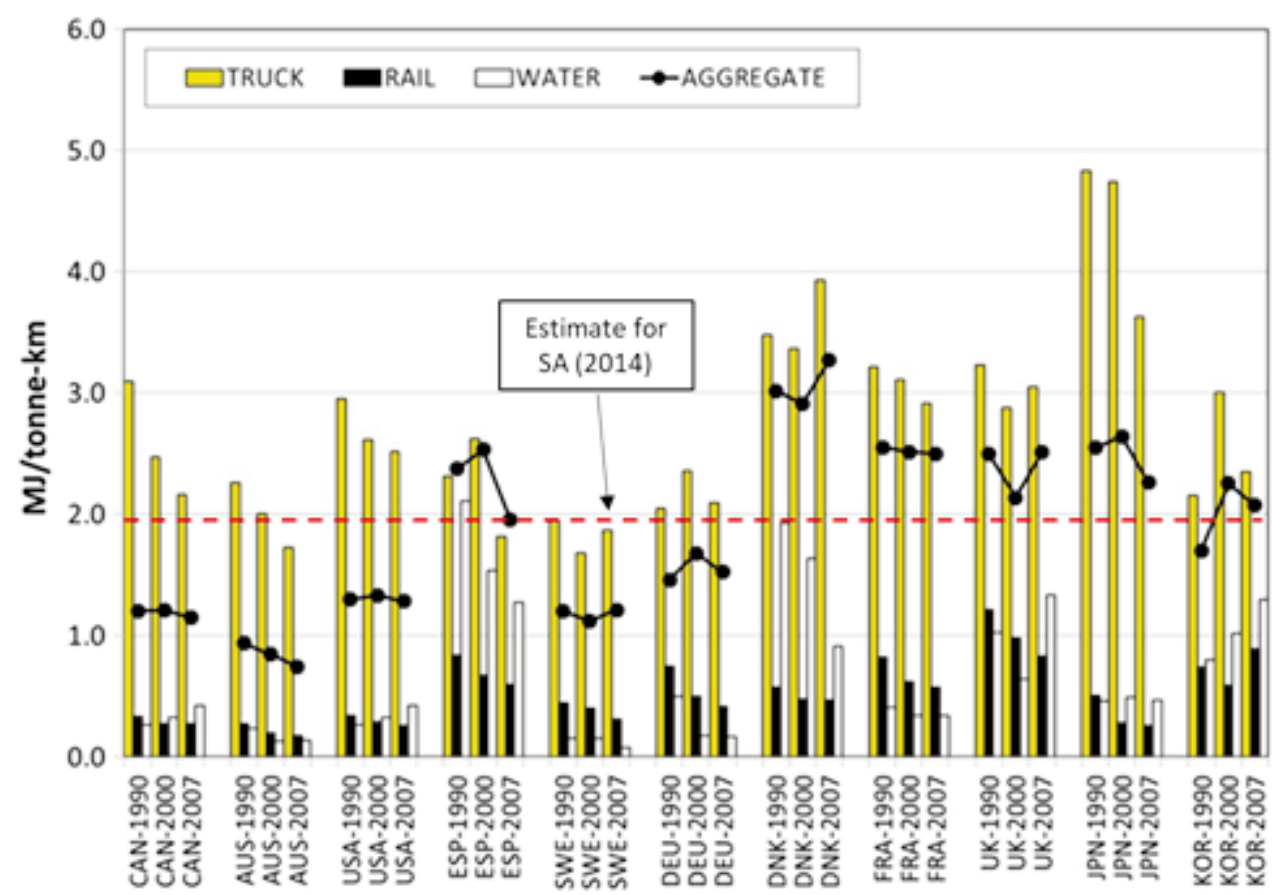

Figure 7: South African road freight (truck) energy intensity in 2014 compared to selected OECD markets 1990-2007 (Eoma et al., 2012, Havenga at al., 2016a)

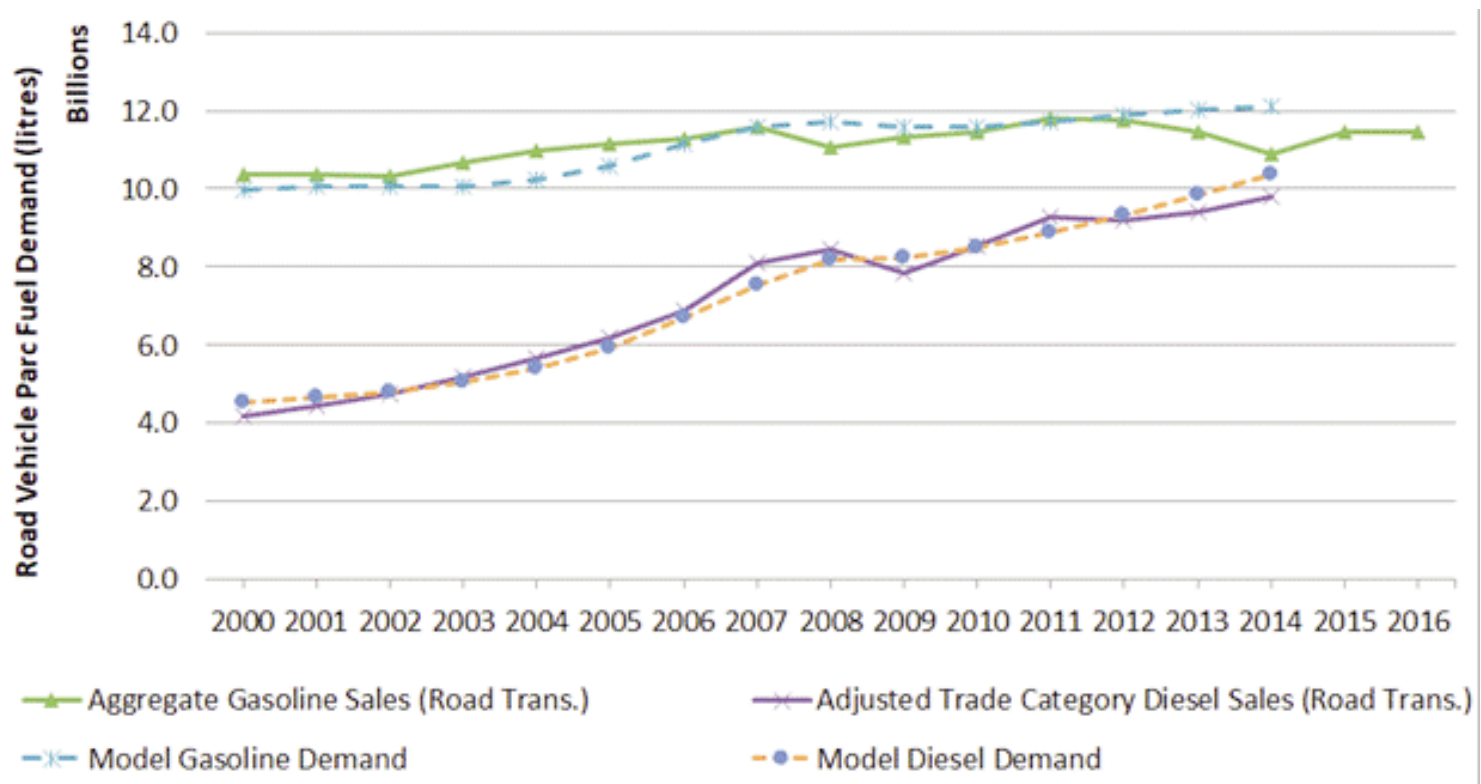

Figure 8. Model's fuel demand vs actual fuel consumption for 2000 to 2014.

Table 7: Comparison of calibration parameters for gasoline cars between Merven et al. (2012) and the present study.

\begin{tabular}{lccccc}
\hline & Year & \multicolumn{2}{c}{ Fuel economy $(\mathrm{l} / 100 \mathrm{~km})$} & \multicolumn{2}{c}{ Annual mileage $(\mathrm{km})$} \\
& & New & Fleet average & New & Fleet average \\
\hline Phase 1 & 2006 & 8.3 & 9.1 & 24000 & 16169 \\
Present study & 2014 & 7.8 & 8.2 & 21000 & 14457 \\
\hline
\end{tabular}

stant, as assumed by the model, future growth in gasoline demand would be sustained, as shown in Figure 8. It can, therefore, be deduced that the recent drop in demand observed in the gasoline sales data is driven by consumers travelling less, while recognising the difficulty of verifying this with- out empirical investigation. Most notably, local authorities do not enforce its capture and the eNatis does not make the limited dataset that has been accumulated from partial completions available, despite the annual vehicle registration form historically having a placeholder for vehicle mileage. The 
assumption of $0.5 \%$ fuel consumption improvement qualifies that the sources of error in the model's fuel demand relative to observed sales is likely to include the following:

- short- and long-run elasticity of demand in response to fuel price variations and average income due to consumers travelling less;

- other effects on demand for private transport like changing urban form and fluctuating congestion; and

- the error in the fuel sales data because of changes in parties responsible for data collection, compounded by changes in the structure of the gasoline-fuels value chain.

The model is intended for passing parameters to a long-term projection model. It does not attempt to integrate price or income elasticities and assumes that consumer preference for annual mileage is constant over the period for a given vehicle age. Considering that the vehicle population grew monotonically over the study window, any significant drop in demand in response to price increase would, therefore, result in significant error. The model responds indirectly to low economic growth through reduced car sales, but, as seen in Figure 5, this effect is relatively dampened compared to the fuel demand volatility seen in Figure 8 . The periods of error in the calibration correspond to price volatility and economic growth variations as shown in Figure 9, with gasoline seemingly more responsive to price fluctuations, and diesel more responsive to GDP/capita variations.

The levelling off of GDP/capita caused by a struggling economy also seems to have depressed demand for gasoline in a longer-run effect relative to the calibration from 2012 onwards, presumably resulting from lower vehicle activity. Figure 8 shows that gasoline demand recovered in 2015 and 2016 in response to significant real price drops, while diesel demand remained low.

Travel time data suggests that congestion and trip distances have increased in South Africa (SEA, 2017), so another possible reason for the observed drop in demand is data error. Historically, liquid fuels were supplied by a regulated oligopoly of the oil majors who collected detailed demand data to enable the complex distribution of fuels. The industry has changed as a result of competition legislation and legislation to enable access to the value chain by historically disadvantaged entrants. This resulted in the responsibility for data collection shifting from one of the majors - firstly to the industry association, SAPIA, and then to the DoE. At the same time a number of independent wholesalers emerged, including Afric Oil, Gulfstream Energy, Mzumbe Oil, Women of Africa Fuel and Oils, Siyanda Petroleum, and Yem Yem Petroleum. These now deal in large volumes in some cases, building on a base of procurement by the state and stateowned enterprises (Transport World Africa, 2014; Greve, 2013). This is to the extent that, while independent wholesalers traditionally were not directly surveyed for the national statistics, they are in some cases believed to be importing fuel independently in large enough volumes to introduce significant statistical uncertainty into the national energy balance(DoE, 2017b). The DoE has, therefore, not only taken on a complex statistical function, but performs this function at the time when the industry is rapidly becoming more complex and difficult to survey. It seems likely, then, that the levelling-off of

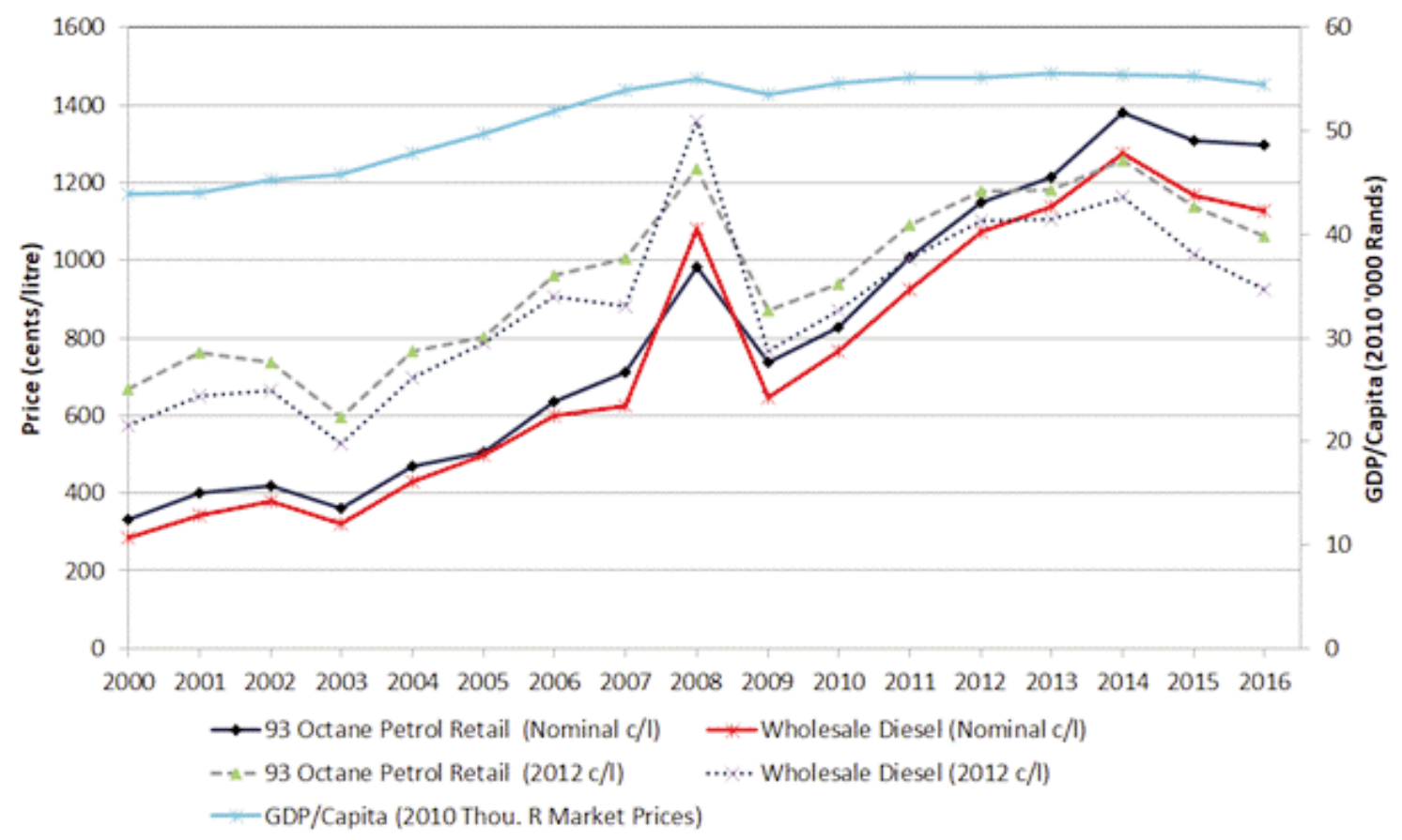

Figure 9. Gauteng gasoline and diesel prices and GDP/capita, 2000-2014. 
gasoline demand is temporary and that economic recovery and ongoing improvement in data collection methods may see the official figure for gasoline demand rise again by the order of $2-3 \%$ per annum until there is a significant penetration of real-world, low-fuel economy vehicles into the vehicle parc.

A key aim of this study was to improve on previous work by calibrating freight demand from the model with that published by the Department of Logistics, University of Stellenbosch. The number of freight vehicle typologies was increased and load factors adjusted, taking some account of the limited consultation (Havenga \& Simpson, 2016b) that was possible with the Department of Logistics within the limitations of the present study. A data-rich output was a calibrated split of ton.km by vehicle typology and by region (corridor, rural and metropolitan), presented in Table 8.

The verified ton.km figure further enabled an estimate of freight energy intensity for the country, as presented in Figure 7. This calculation, however, required an estimate of the diesel sales to road transport as a calibration target and this can be considered uncertain given that it was derived from a trend-smoothing exercise using sales data disaggregated by 'trade category', a legacy classification that gives limited guidance on the commercial activity the fuel was used for. The DoE is in the process of moving to International Standard Classifications in its questionnaires (DoE, 2017b), which may enable more certain estimates in the future. A further uncertainty was that the diesel demand by Eskom was notably high during 2010-2015, and this must be accounted for in the trend analysis. In addition, the energy balances for those years (as published at the time of writing) suggest that the Eskom consumption was excluded from trade category data, the total of which is equal to total final consumption excluding transformation. Liaison with the DoE (2018), however, confirmed that the Eskom consumption is indeed included in the trade category data and this was, therefore, adjusted downwards by the additional amount before the share of road transport was estimated. Improved statistical methods will, however, only partly reduce uncertainty. There is no substitute for empirical sector studies and far more needs to be understood about energy use in the agriculture, construction and mining sectors, if there should be any certainty that the residual diesel in the calibration reflects that used by stationary and off-road activities.

The new freight data presented by the present study, however, represents a rare attempt to achieve agreement in key parameters across modelling efforts by different teams in related fields, and will hopefully be an example for improved collaboration, more effective validation, and better support for policy and planning in the energy and transport spheres.

\section{Conclusions}

A vehicle parc model for South Africa incorporating detailed estimates for efficiencies and activity levels for a variety of vehicle typologies was developed and calibrated against national sales of gasoline and diesel over 15 years, from 2000-2014. The model

Table 8: Freight demand calibration output by vehicle typology and operating environment.

\begin{tabular}{|c|c|c|c|c|c|c|c|c|c|}
\hline & \multicolumn{4}{|c|}{ Assumptions (\%) } & \multicolumn{5}{|c|}{ Model freight demand (billion ton. $\mathrm{km}$ ) } \\
\hline $\begin{array}{l}\text { SATIM } \\
\text { vehicle type }\end{array}$ & $\begin{array}{l}\text { Load factor } \\
\text { (ton/veh) }\end{array}$ & $\begin{array}{c}\text { Share of } \\
\text { ton. } \mathrm{km} \\
\text { that is corridor }\end{array}$ & $\begin{array}{c}\text { Share of } \\
\text { ton. } \mathrm{km} \\
\text { that is metro }\end{array}$ & $\begin{array}{c}\text { Share of } \\
\text { ton. } \mathrm{km} \\
\text { that is rural }\end{array}$ & Total & $\begin{array}{l}\text { \% share of } \\
\text { demand }\end{array}$ & Corridor & $\begin{array}{l}\text { Metro- } \\
\text { politan }\end{array}$ & Rural \\
\hline HCV1Diesel & 1.4 & 0.4 & 86 & 14 & 7.77 & 3.4 & 0.03 & 6.67 & 1.07 \\
\hline HCV1Gasoline & 1.5 & 8 & 75 & 17 & 0.06 & 0.0 & 0.00 & 0.04 & 0.01 \\
\hline HCV2Diesel & 2.5 & 10 & 54 & 36 & 2.38 & 1.0 & 0.24 & 1.28 & 0.86 \\
\hline HCV3Diesel & 5.0 & 24 & 62 & 14 & 16.19 & 7.0 & 3.81 & 10.11 & 2.27 \\
\hline HCV4Diesel & 7.9 & 38 & 40 & 22 & 6.47 & 2.8 & 2.46 & 2.61 & 1.40 \\
\hline HCV5Diesel & 10.9 & 53 & 31 & 16 & 3.96 & 1.7 & 2.11 & 1.22 & 0.63 \\
\hline HCV6Diesel & 20.7 & 54 & 24 & 22 & 142.10 & 61.4 & 76.52 & 34.18 & 31.41 \\
\hline HCV7Diesel & 18.6 & 55 & 16 & 29 & 31.51 & 13.6 & 17.29 & 4.97 & 9.26 \\
\hline HCV8Diesel & 18.4 & 57 & 15 & 28 & 1.24 & 0.5 & 0.71 & 0.18 & 0.35 \\
\hline HCV9Diesel & 21.9 & 57 & 17 & 26 & 0.70 & 0.3 & 0.40 & 0.12 & 0.18 \\
\hline LCVDiesel & 0.4 & 0 & 84 & 16 & 8.89 & 3.8 & 0.03 & 7.46 & 1.40 \\
\hline LCVGasoline & 0.4 & 0 & 82 & 18 & 9.98 & 4.3 & 0.02 & 8.19 & 1.78 \\
\hline \multicolumn{10}{|c|}{ tkm calibration comparison } \\
\hline & & Total & & & 231.3 & 100.0 & 103.6 & 77.0 & 50.6 \\
\hline \multicolumn{5}{|c|}{ Dept of Logistics (Havenga, et al., 2016a) } & 231.0 & & 103.4 & 77.0 & 50.6 \\
\hline \multicolumn{5}{|c|}{ Calibration error (\%) -0.11} & 0.20 & 0.00 & 0.12 & & \\
\hline
\end{tabular}


has 11 freight vehicle typologies that were used to develop a parallel calibration of the ton. $\mathrm{km}$ demand of the model with that estimated by the freight demand model of the Department of Logistics, University of Stellenbosch for 2014 (Havenga, et al., 2016a). This enabled an estimate of the energy intensity of freight transport for the country (1.9-2.0 $\mathrm{MJ} /$ ton. $\mathrm{km}$ ) to be made, one that can be used to benchmark the energy efficiency of the freight logistics industry. The model output furthermore provides a data-rich picture of the activity levels, efficiencies and contribution to meeting passenger and freight demand of different vehicle typologies.

Some interesting trends emerged from the time series of input and output data, as follows:

- Steady dieselisation of the light vehicle fleet has been occurring.

- The fuel economy of the light vehicle fleet has been improving only very slowly, if at all.

- The consumption of gasoline in particular has dropped off steadily since 2011 and seems to relate to lower activity levels, driven by economic factors.

The following important data issues emerged from the study:

- In general, the quality of energy related data received was of concern in all the major sources: fuel sales and registration statistics collated by government in partnership with industry, and vehicle sales data collated by industry and sold by a private concern as proprietary data. The following were key issues:

- Metadata is sparse or non-existent.

- Obvious validation checks have sometimes not been performed - for example, the sum of disaggregates of the same commodity might not match or time series of quantities have implausible step changes or trends.

- A poor understanding of the technical details is sometimes apparent - for example, the difference between $\mathrm{CO}_{2}$ emissions and emissions standards for local air pollutants.

- Older data has been removed from the public record, so that developing time series is difficult.

- The sparseness of activity data - for example, annual mileage over the life of the vehicle or vehicle occupancy and load factors necessitated many assumptions.

- Diesel use in the agriculture, construction and mining sectors needs to be better understood in order to make allocations of diesel use to sectors for modelling and greenhouse gas inventory purposes with any certainty.

This study suggested that better energy policy and planning going forward requires stakeholders to collaborate to improve the quantity, quality and accessibility of energy and environment data.

Transport planning and planning for energy for transport are particularly high on the national agen$\mathrm{da}$, with congestion in cities increasing, public transport networks expanding at great expense, and the costs of energy imports rising. The data-rich picture provided by this model is, therefore, a useful input to many policy activities other than the projection of energy demand. For example, extensions of this type of model are particularly useful for rapid assessment of the impacts on demand of disruptive transport technologies, including battery electric vehicles, hybrid electric vehicles and hydrogen fuel cell vehicles. This has relevance to the large gasoline fuels sector in the country, which could be severely affected by penetration of these technologies. Future work will aim to explore these impacts.

\section{Note}

1. Supplementary material can be found at https://journals.assaf.org.za/jesa/article/view/2774.

\section{References}

Altieri, K. E., Trollip, H., Caetano, T., Hughes, A., Merven, B., \& Winkler, H. (2016). Achieving development and mitigation objectives through a decarbonization development pathway in South Africa. Climate Policy 16(sup1): S78-S91.

Armenia, S., Baldoni, F., Falsini, D. \& Taibi, E., 2010. A system dynamics energy model for a sustainable transportation system. Paper delivered at the ISDC Conference 2010, Seoul, South Korea.

Bell, A., Stone, A. \& Harmse, B., 2003. Final report investigation (desk top study) into the optimum future octane grade structure for South Africa Excel. Pretoria: Department of Energy (then Department of Minerals and Energy), Republic of South Africa.

CSIR (Council for Scientific and Industrial Research). 2013. 10th Annual state of logistics survey for South Africa 2013 - Bold steps forward. CSIR, Pretoria, South Africa.

DEA (Department of Environmental Affairs). 2007. Long term mitigation scenarios. Pretoria: DEA (then Department of Environment and Tourism), Republic of South Africa.

DEA (Department of Environmental Affairs). 2014. South Africa's greenhouse gas (GHG) mitigation potential analysis. Pretoria: DEA (then Department of Environment and Tourism), Republic of South Africa.

DoE (Department of Energy). 2013. National energy balance for the Republic of South Africa, version 1. Pretoria: DoE.

DoE (Department of Energy). 2012. Integrated energy plan 2012, Pretoria: DoE, republic of South Africa.

DoE (Department of Energy). Integrated energy plan. Part 1 of 3 ed. Pretoria: DoE, republic of South Africa.

DoE (Department of Energy). 2017b. Personal communication. 
DoE (Department of Energy). 2017. Excel spreadsheet fuel sales by trade category 1998-2015. Personal communication.

DoE (Department of Energy). 2018. Personal communication.

DoT (Department of Transport). 2009. National transport master plan (NATMAP) 2050 modelling report, Pretoria: Department of Transport, Republic of South Africa.

EEA (European Environment Agency) 2016. Monitoring $\mathrm{CO}_{2}$ emissions from new passenger cars and vans in 2015. European Environment Agency, Copenhagen, Denmark.

eNaTiS (Electronic National Administration Traffic Information System). 2016. Live vehicle population as per the national traffic information system 20002016. Available at:

http://www.enatis.com/index.php/statistics/13-livevehicle-population/537-vehicle-population-statisticsfor-june-to-july-2016. [Accessed January 2017].

Energy Research Centre, 2015. South Africa's proposed nuclear build plan: An analysis of the potential socioeconomic risks. Technical report. Energy Research Centre, University of Cape Town, Cape Town, South Africa.

Eoma, J., Schipper, L. \& Thompson, L., 2012. We keep on truckin': Trends in freight energy use and carbon emissions in 11 IEA countries. Energy Policy 45: 327-341.

https://doi.org/10.1016/j.enpol.2012.02.040

European Commission, 2017. Reducing CO2 emissions from heavy-duty vehicles. Available at: https://ec.europa.eu/clima/policies/transport/vehicles/heavy_en\#tab-0-0.

Gajjar, H. \& Mondol, J., 2015. Technoeconomic comparison of alternative vehicle technologies for South Africa's road transport system. International Journal of Sustainable Transportation 10(7): 579-589. https://doi.org/10.1080/15568318.2015.1026007

GFEI (Global Fuel Economy Initiative). 2016. Fuel economy state of the world 2016 - Time for global action. Global Fuel Economy Initiative.

Giannakidis, G., Labriet, M., Ó Gallachóir, B. \& Tosato, G. (eds). 2015. Informing energy and climate policies using energy systems models: Insights from scenario analysis increasing the evidence base. Springer.

Greve, N., 2013. Transnet awards landmark R15.5bn fuel contract to 9 black, women-owned firms. Engineering News, December 2013.Available at: http://www.engineeringnews.co.za/article/transnetawards-landmark-r155bn-fuel-contract-to-9-blackwomen-owned-firms-2013-12-05/rep_id:4136.

Havenga, J. \& Simpson, Z. 2016b. Personal communication on trends in freight logistics in South Africa.

Havenga, J., Simpson, Z. K. D., de Bod, A. \& Braun, M., 2016a. Logistics barometer South Africa 2016. Stellenbosch University, Stellenbosch, South Africa.

Heywood, J. 1988. Internal combustion engines fundamentals. Singapore: McGraw Hill.

ICCT (International Council on Clean Transportation). 2016. From laboratory to road: A 2016 update of official and 'real-world' fuel consumption and $\mathrm{CO}_{2}$ values for passenger cars in Europe. The International Council on Clean Transportation.

IEA (International Energy Agency). 2011. Sustainable mobility project (SMP) dodel - Excel spreadsheet forwarded by email. International Energy Agency.

Jackson, M., 2011. Technologies to improve fuel efficiency of heavy trucks. Presentation at workshop: European Commission, Reducing greenhouse gas emissions from heavy-duty vehicles: policy options, development and prospects - International workshop.

Jackson, T., 2001. Fleet characterization data for MOBILE6: Development and use of age distributions, average annual mileage accumulation rates, and projected vehicle counts for use in MOBILE6. Assessment and Modeling Division Office of Transportation and Air Quality. U.S. Environmental Protection Agency.

Lightstone Auto. 2015. Vehicle sales by type with associated technical data 1981-2014. Excel spreadsheet collated and distributed on behalf of the National Association of Automobile Manufacturers of South Africa.

Merven, B., Arndt, C. and Winkler, H., 2017. The development of a linked modelling framework for analysing the socioeconomic impacts of energy and climate policies in South Africa. WIDER Working Paper 2017/40.

Merven, B., Stone, A., Hughes, A. \& Cohen, B., 2012. Quantifying the energy needs of the transport sector for South Africa: A bottom-up model. Energy Research Centre, University of Cape Town, Cape Town, South Africa.

Metrorail, 2007. National facts. Available at: http://www.metrorail.co.za/National_Facts1.html

NAAMSA (National Association of Automobile Manufacturers of South Africa ) / SAPIA (South African Petroleum Industry Association) Working Group. 2009. Excel spreadsheet of the NAAMSA / SAPIA working group vehicle car parc as used for the SAPIA gasoline and diesel study. Forwarded by email August 2009.

OICA (International Organization of Motor Vehicle Manufacturers), 2016. Motorization rate 2014 worldwide. [Online].

RFA (Road Freight Association) 2009. Vehicle cost schedule.

Road Traffic Management Corporation, 2009. Road traffic report - year 2008. Road traffic Management Corporation, an agency of the Department of Transport, Republic of South Africa..

SEA (Sustainable Energy Africa). 2017. Sustainable energy solutions for South African local government - a practical guide. Cape Town: Sustainable Energy Africa.

Stats SA (Statistics South Africa). 2013. Calculated from the published survey data files for the National Household Travel Survey 2013; available from Datafirst, University of Cape Town. Datafirst, University of Cape Town.

StatsSA (Statistics South Africa) 2016a. Statistical release P0302, Mid-year population estimates 2016. Statistics South Africa. 
Stats SA (Statistics South Africa). 2016b. GDP P0441

Annual, quarter and regional revisions tables - Q4 2016 Excel File. Statistics South Africa.

Stone, A.. 2004. Creating a national database of traffic based vehicle emissions factors and vehicle parc Excel spreadsheet model supporting this publication. Cape Town: National Association Of Clean Air Western Cape symposium.

Stone, A. \& Bennett, K., 2001. A bulk model of emissions from South African diesel commercial vehicles. Energy Research Centre, University of cape Town, Cape Town, South Africa.

Transport and Environment, 2015. Europe's lost decade of truck fuel economy. Transport \& Environment Briefing.

Transport World Africa, 2014. Shaking up downstream petroleum market. Available at: http://www.transportworldafrica.co.za/2014/10/24/shaking-up-downstream-petroleum-market/.

University of California at Riverside, 2002. Kenya vehicle activity study, Nairobi: Global Sustainable Systems Research.

Vanderschuren, M., 2011. Personal communication Excel spreadsheet of vehicle model outputs. Department of Civil Engineering, University of Cape Town, Cape Town, South Africa. 